\title{
Evaluation Of The Toxicological Effects Manifested After Long term Administration Of Aqueous Calotropis procera Plant Extract In Male And Female Rabbits \\ Mohamed A. Shahat ${ }^{1}$ and Ahmed M.A. Shihata ${ }^{2}$ \\ ${ }^{1}$ Department of Zoology, Faculty of Science, AlAzhar University at Assiut, Egypt. ${ }^{2}$ Chemical lab -Medico. Legal-Ministry of justise "Forensic chemist"
}

\begin{abstract}
Background: Treatment with aqueous extract of Calotropis Procera was examined only for short periods. So, The present study was designed to examine the influences of long term administrations of aqueous extract of Calotropis Procera on male and female rabbits.
\end{abstract}

Material and methods: The extract was daily oral administered to thirty adult rabbits divided into two sets each set contain 3 groups (5/each) for a period of 8 weeks. The doses administered were 80 and $40 \mathrm{mg} / \mathrm{kg}$ body weight as high and low doses for both male and female test groups.

Percentage of body weight change, serum biochemistry (Alanine amino transferases (ALAT), aspartate amino transferases (ASAT), Alkaline phosphatase, total protein, albumin, globulin, A/G ratio, urea and creatininre), hematological parameters ( $\mathrm{PCV}, \mathrm{WBCs}, \mathrm{RBCs}$, Platelets and $\mathrm{Hb}$ ) and the blood indices (M.C.V., M.C.H. and M.C.H.C.) were examined.

Results: Results showed that there was no mortality or clinical signs observed among the treatment and the control groups. No significant changes in the percentage of body weight gain, hematological parameters, blood indices has been noticed in all treated groups

Highly significant decreases in serum total protein and albumin in male and female rabbits has been recorded at high doses. While the globulin and A/G ratio revealed no significant changes. Serum ASAT, urea and creatinine levels were highly significant increases $(\mathrm{P}<0.01)$ and the activity of ALAT and ALP was significant increases $(\mathrm{P}<0.05)$ in male and female rabbits at high doses only.

Conclusions: Some toxicological effects were observed after administration of aqueous leaves extract of Calotropis Procera at high doses in the long term for male and females rabbits

Key word: Calotropis Procera, biochemical parameters, Haematology; body weight gains, rabbits

\section{INTRODUCTION}

Calotropis procera is a species of flowering desert plant in the dogbane family, Apocynaceae, that is native to North Africa, Tropical Africa, Western Asia, South Asia, and Indochina (Miller \& Morris, 1987). The excavation at Helwan in Egypt showed that the plant was in use in Neolithic period in Egypt (Greiss, 1955). It is known as Ushar or Madar in Greeco-Arab medicine and known as Apple of
Sodom, a name derived from the Hebrew Tapuah Sdom also,the plant known as aak for its medicinal properties in Ayurveda (Oudhia \& Dixit, 1994).The green globes are hollow but the flesh contains a toxic milky sap that is extremely bitter and turns into a gluey coating resistant to soap (Kumar et al., 2004).

Preliminary phytochemical screening of fresh leaves of Calotropis procera in water 
extract revealed the presence of phenols, saponins, tannins, glycosides and mixtures of cardenolides (Murti et al., 2010; Pouokam et al., 2011 and Soto et al., 2011).

Calotropis procera is used in traditional system of medicine for the treatment of variety of disease conditions that include leprosy, ulcers, and tumors and piles, diarrheoan somatic, sinus fistula and skin diseases. The leaf part is used to treatment of jaundice (Murti et al., 2010) while, milky white latex obtained from the plant exhibits potent anti-inflammatory activity in various animal models that is comparable to standard anti-inflammatory drugs ( Dewan et al., 2000 and Sangraula et al., 2002).

Toxicity of $C$. procera is reported after incidental ingestion of fresh leaves of Giant milkweed by sheep (ruminants) in the form of anorexia and diarrhea, (Mahmoud et al., 1979). The Consumption of this plant leads to severe poisoning to livestock as well as man (Lewis and Elvin-Lewis, 1977). Administration of Giant milkweed leaves to sheep is responsible of tachycardia and transitory cardiac arrhythmia, it also has radiotoxic \& hepatotoxic effects after 30 min of administration (District et al., 1983).

The controversial reports about poisoning effects of this plant confused many scientist. So, we planed this work to evaluate and compare the toxic effects of C. procera aqueous extract leaves on both sex of rabbits. Also, to evaluate the dose which could be used as medicinal plant for long term without side effects.

\section{MATERIALS AND METHODS}

\section{Collection of Plant and extract preparation}

Fresh leaves of Calotropis procera used in this experiment were harvested from Fadan Karshe in Kaduna State, Nigeria .The plant was identified at the Federal College of Forestry, Plateau State, Jos, Nigeria. Two and half $\mathrm{kg}$ of the fresh leaves had been extracted with distilled water for 24 hours and then dried at $400 \mathrm{C}$ in hot air oven in the Laboratory of the Biochemistry Department of NVRI, Vom to obtain dry crude extract of the Calotropis procera. The stock solution was prepared by dissolving $10 \mathrm{gm}$ of the dried aqueous extract in $250 \mathrm{ml}$ of distilled water $(40 \mathrm{mg} / \mathrm{ml})$. The stock solution was stored in the refrigerator at $4 \mathrm{C}$.

\section{Experimental animals and Groups}

Thirty white New-Zealand adult male and female rabbits $11 \pm 2$ week old and weighing 1.5 $\pm 0.3 \mathrm{~kg}$ in average were divided into 6 groups, 3 male and 3 female groups designated as (G1) and (G4) control, (G2) and (G5) daily treatment with high dose aqueous extract of Calotropis procera $(80 \mathrm{mg} / \mathrm{kg}$ body weight) for 8 weeks and (3) and (6) daily treatment with low dose of aqueous extract of Calotropis procera $(40 \mathrm{mg} / \mathrm{kg}$ body weight) for 8 weeks .

\section{Collection of blood sample}

At the end of the experiment, all the surviving animals were sacrificed and blood was collected by cardiac puncture and venipuncture into tow bottles, the first one containing ethylene diamine tetraacetate (EDTA) for haematology analysis and the second bottle without EDTA. Sera were separated by centrifugation at 3000 rpm for 15 minutes and keep at - $40{ }^{\circ} \mathrm{C}$ till used for biochemical assays.

\section{Percentage of body weight gain:}

All animals groups (control and treated) were individually weighed in order to detect any changes in their body weights. The percentage of body weight gain was calculated as follows 
Percentage of body weight gain $=$

Final weight - Initial weight

Initial weight X 100

\section{Biochemical analysis}

Serum total protein was evaluated according to the method of Doumas et al. (1975) and serum albumin by method of Doumas (1971), while Alanine amino transferases (ALAT) and aspartate amino transferases (ASAT) were determined as the method of Reithman and Frankel (1957) and the Alkaline phosphatase (ALP) by the method of Babson (1965).

Serum creatinine levels were determined by methods of Heinegard and Tiderstrom (1973), while serum urea was determined as the method of Marsh et al. (1965).

\section{Hematological analysis}

The hematological parameters ; Packed Cell Volume (PCV), hemoglobin concentration $(\mathrm{Hb})$, Red Blood Cells count (RBC), White Blood Cells count (WBC) and blood Platelets count were determined by methods described by

Baker et al. (1998).

The blood indices, mean corpuscular volume (MCV), mean corpuscular haemoglobin (MCH) and mean corpuscular haemoglobin concentration (MCHC) for particular blood samples were also calculated as the following.

Mean corpuscular volume (M.C.V.)

Packed Cell Volume (PCV) X 10

M.C.V. = $\mathrm{RBC}$ in millions/cu.mm.

Mean Corpuscular Hemoglobin (M.C.H.)

M.C.H. = $\frac{\text { gm. Hgb./100 ml. X } 10}{\text { RBC in millions/cu. mm. }}$

$\begin{array}{lll}\text { Mean Corpuscular } & \text { Hemoglobin } \\ \text { concentration }\end{array}$

$$
\text { M.C.H.C. = } \frac{\text { gm. Hgb./100 ml. X } 100}{\text { Packed Cell Volume (PCV) }}
$$

\section{Statistical analysis of the data:}

The obtained data were expressed as a mean \pm standard error (SE) and the analysis were revised by Quattro Pro statistical program for windows program version 2- Microsoft Windows version 7. The significance of difference between the means was calculated according to Student's ttest. Statistical significance was accepted at $P<$ 0.05 .

\section{RESULTS}

The results for $\%$ of body weight gain are shown in table1 below. All the rabbits showed a consistent increase in weight. The result is not surprising as the rabbits did not show any sign of anorexia and were feeding very well (table. 1). The hematological test results for male and female test groups are shown in tables 2 and 3 .The results revealed no significant difference between the groups with all the values obtained lying within the normal range.

The data were tabulated in table (4) revealed highly significant decreases in serum total protein and albumin in males and females at high doses. While the globulin and $\mathrm{A} / \mathrm{G}$ ratio revealed no significant difference between the groups.

The represented data (Table, 5and 6) indicated that marked elevation in the activity of ASAT, urea and creatinine, these elevations were statistically highly significant $(\mathrm{P}<0.01)$ in males and females at high doses. Furthermore, the levels of ALAT (IU/L) and ALP (IU/L) with the same previous dose showed statistically significant increases $(\mathrm{P}<0.05)$ in males and females. 
Table (1): Effect of daily oral administration of low and high dose (40 and $80 \mathrm{mg} / \mathrm{kg}$ body weight) of Calotropis procera aqueous extract on the percentage of weight gain in male and female rabbits.

\begin{tabular}{|c|c|c|}
\hline Sex & Groups & \%Weight gain \\
\hline \multirow{3}{*}{$\frac{0}{\frac{0}{\sigma}}$} & Control(G1) & $20.00 \pm 1.52$ \\
\hline & High dose (G2) & $27.15 \pm 3.44$ \\
\hline & Low dose(G3) & $22.16 \pm 2.87$ \\
\hline \multirow{3}{*}{ 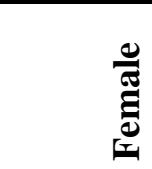 } & Control(G4) & $33.33 \pm 4.22$ \\
\hline & High dose(G5) & $33.57 \pm 3.11$ \\
\hline & Low dose(G6) & $22.93 \pm 3.10$ \\
\hline
\end{tabular}

Table (2): Values of the hematological parameters after oral administration of low and high dose (40 and $80 \mathrm{mg} / \mathrm{kg}$ body weight) of Calotropis procera aqueous extract in male and female rabbits

\begin{tabular}{|c|c|c|c|c|c|c|}
\hline Sex & Groups & $\begin{array}{l}\text { PCV } \\
(\%)\end{array}$ & $\begin{array}{c}\text { Hb } \\
(\mathrm{gm} / \mathrm{dl})\end{array}$ & $\begin{array}{c}\text { WBC } \\
\left(\times 10^{3} / \mathrm{mm}^{3}\right)\end{array}$ & $\begin{array}{l}\text { Platelets } \\
(\mathbf{x 1 0} / 1)\end{array}$ & $\begin{array}{c}\text { RBC } \\
\left(\times 10^{6} / \mathrm{mm}^{3}\right)\end{array}$ \\
\hline \multirow{3}{*}{$\sum^{\frac{0}{\sigma}}$} & Control(G1) & $36.40 \pm 03.65$ & $12.76 \pm 1.05$ & $09.52 \pm 00.85$ & $198.00 \pm 16.08$ & $6.23 \pm 0.23$ \\
\hline & High dose (G2) & $38.40 \pm 02.97$ & $13.89 \pm 0.23$ & $10.70 \pm 00.61$ & $193.40 \pm 22.20$ & $6.70 \pm 0.44$ \\
\hline & Low dose(G3) & $37.20 \pm 03.03$ & $13.98 \pm 0.28$ & $09.90 \pm 01.16$ & $230.00 \pm 34.08$ & $6.56 \pm 0.25$ \\
\hline \multirow{3}{*}{ 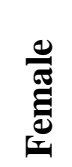 } & Control(G4) & $36.25 \pm 04.79$ & $12.55 \pm 02.72$ & $09.43 \pm 00.38$ & $205.50 \pm 14.80$ & $5.96 \pm 1.35$ \\
\hline & High dose(G5) & $37.60 \pm 03.58$ & $11.99 \pm 01.89$ & $10.22 \pm 01.35$ & $227.00 \pm 16.09$ & $6.00 \pm 0.43$ \\
\hline & Low dose(G6) & $37.40 \pm 04.97$ & $12.62 \pm 01.61$ & $09.66 \pm 02.40$ & $202.40 \pm 27.94$ & $6.26 \pm 0.52$ \\
\hline
\end{tabular}

Table (3): Values of some blood indices after oral administration of low and high dose (40 and $80 \mathrm{mg} / \mathrm{kg}$ body weight) of Calotropis procera aqueous extract in male and female rabbits

\begin{tabular}{|c|c|c|c|c|}
\hline Sex & Groups & $\begin{array}{r}\text { MCV } \\
\text { (fl) }\end{array}$ & $\begin{array}{r}\mathrm{MCH} \\
(\mathbf{p g})\end{array}$ & $\begin{array}{r}\mathrm{MCHC} \\
(\mathrm{g} / \mathrm{dL})\end{array}$ \\
\hline \multirow{3}{*}{$\sum^{\frac{0}{\sigma}}$} & Control(G1) & $58.42 \pm 4.62$ & $19.38 \pm 2.56$ & $35.06 \pm 1.74$ \\
\hline & High dose (G2) & $57.31 \pm 3.31$ & $19.54 \pm 2.84$ & $36.17 \pm 2.35$ \\
\hline & Low dose(G3) & $56.71 \pm 2.36$ & $20.07 \pm 1.03$ & $37.58 \pm 3.33$ \\
\hline \multirow{3}{*}{ 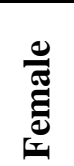 } & Control(G4) & $60.82 \pm 4.11$ & $18.50 \pm 1.55$ & $34.86 \pm 2.09$ \\
\hline & High dose(G5) & $60.67 \pm 5.89$ & $16.32 \pm 2.99$ & $32.71 \pm 3.77$ \\
\hline & Low dose(G6) & $59.74 \pm 3.00$ & $19.27 \pm 1.12$ & $33.74 \pm 2.87$ \\
\hline
\end{tabular}

The result expressed in means \pm SE (standard error) 
Table (4): Effect of daily oral administration of low and high dose (40 and $80 \mathrm{mg} / \mathrm{kg}$ body weight) of Calotropis procera aqueous extract on serum total protein, albumin, globulin and $A / G$ ratio in male and female rabbits.

\begin{tabular}{|c|c|c|c|c|c|}
\hline Sex & Groups & Total protein & Albumin & Globulin & A/G ratio \\
\hline \multirow{3}{*}{$\sum^{\frac{0}{\pi}}$} & Control(G1) & $5.55 \pm 0.226$ & $3.41 \pm 0.174$ & $2.14 \pm 0.197$ & $1.59 \pm 0.123$ \\
\hline & High dose (G2) & $4.77^{* *} \pm 0.095$ & $2.70^{* *} \pm 0.080$ & $2.07 \pm 0.086$ & $1.30 \pm 0.83$ \\
\hline & Low dose(G3) & $5.10 \pm 0.232$ & $3.08 \pm 0.156$ & $2.24 \pm 0.097$ & $1.52 \pm 0.55$ \\
\hline & Control(G4) & $5.70 \pm 0.257$ & $3.42 \pm 0.111$ & $2.24 \pm 0.225$ & $1.53 \pm 0.109$ \\
\hline & High dose (G5) & $4.82^{* *} \pm 0.111$ & $2.60^{* *} \pm 0.075$ & $2.22 \pm 0.156$ & $1.17 \pm 0.097$ \\
\hline & Low dose(G3) & $5.20 \pm 0.127$ & $3.08 \pm 0.117$ & $2.12 \pm 0.066$ & $1.45 \pm 0.069$ \\
\hline
\end{tabular}

Table (5): Effect of daily oral administration of low and high dose (40 and $80 \mathrm{mg} / \mathrm{kg}$ body weight) of Calotropis procera aqueous extract on serum ASAT (IU/L), ALAT (IU/L) and $\operatorname{ALP}(I U / L)$ in male and female rabbits

\begin{tabular}{|c|c|c|c|c|}
\hline Sex & Groups & AST (IU/L) & ALT (IU/L) & $\operatorname{ALP}(\mathbf{I U} / \mathbf{L})$ \\
\hline \multirow[b]{3}{*}{$\frac{\stackrel{0}{\pi}}{\sum}$} & Control(G1) & $91.42 \pm 17.11$ & $84.2 \pm 18.23$ & $46.48 \pm 7.67$ \\
\hline & High dose (G2) & $139.33^{* *} \pm 29.07$ & $97.77^{*} \pm 9.15$ & $64.39^{*} \pm 11.89$ \\
\hline & Low dose(G3) & $100.39 \pm 19.43$ & $95.06 \pm 16.09$ & $48.37 \pm 8.55$ \\
\hline \multirow{3}{*}{ 䒕 } & Control(G4) & $89.50 \pm 18.01$ & $83.83 \pm 15.22$ & $45.75 \pm 8.35$ \\
\hline & High dose(G5) & $119.00^{* *} \pm 25.74$ & $97.22^{*} \pm 5.98$ & $61.86^{*} \pm 9.55$ \\
\hline & Low dose(G6) & $96.25 \pm 14.32$ & $88.33 \pm 12.06$ & $53.96 \pm 5.45$ \\
\hline
\end{tabular}

Table (6): Effect of daily oral administration of low and high dose (40 and $80 \mathrm{mg} / \mathrm{kg}$ body weight) of Calotropis procera aqueous extract on serum urea $(\mathrm{mg} / \mathrm{dl})$ and creatinine $(\mathrm{mg} / \mathrm{dl})$ in male and female rabbits.

\begin{tabular}{|c|c|c|c|}
\hline Sex & Groups & $\begin{array}{c}\text { Urea } \\
\text { (mg/dl) }\end{array}$ & $\begin{array}{c}\text { Creatinine } \\
(\mathrm{mg} / \mathrm{dl})\end{array}$ \\
\hline \multirow{3}{*}{$\frac{0}{\pi}$} & Control(G1) & $34.44 \pm 5.25$ & $0.68 \pm 0.12$ \\
\hline & High dose (G2) & $48.66^{* *} \pm 6.30$ & $1.17^{* * *} \pm 0.24$ \\
\hline & Low dose(G3) & $34.32 \pm 3.73$ & $0.89 \pm 0.14$ \\
\hline \multirow{3}{*}{ } & Control(G4) & $32.72 \pm 4.33$ & $0.59 \pm 0.13$ \\
\hline & High dose(G5) & $50.48^{* *} \pm 7.49$ & $1.30^{* *} \pm 0.26$ \\
\hline & Low dose(G6) & $37.87 \pm 5.89$ & $0.85 \pm 0.19$ \\
\hline
\end{tabular}

The result expressed in means $\pm \mathrm{SE}$ (standard error)

$* \quad=$ Significant $(\mathrm{P}<0.05)$

$* *$ = Highly significant $(\mathrm{P}<0.01)$ 


\section{DISCUSSIONS}

Medicinal plants being an effective source of both traditional and modern medicines are genuinely useful for primary health care. Although many investigators has been reported that $C$. procera possess various medicinal functions, but it has some unknown toxics effects. This work designed to investigates the influence of the chronic aqueous leaves extract of $C$. procera on both sex of rabbits.

The results of the present study (Table, 1) revealed that, percentage of weight gain of all rabbits treated with aqueous leaves extract of $C$. procera showed no significant changes in these body weight. These results agreement with data observed by Mbako et al. (2009), in rabbits and Radunz et al. (1983), in cattle and sheep.

On other hand, C. procera plants causes anaemia and weight loss as a results of mild diarrhoea and loss of fluid or serous discharge could be attributed to erosion of mucous lining of the gastro-intestinal (Mahmoud et al., 1979 and Dada et al., 2002)

In all tested groups, the values of haematological parameters $(\mathrm{PCV}, \mathrm{Hb} \mathrm{WBC}$, $\mathrm{RBC}$ and platelets) as well as blood indices (MCV, MCH and MCHC) showed no statistical significance and these values still remained within normal reference ranges, these data are in agreement with the reports of El- Shafey et al. (2011) and Guy et al. (2011) In contradiction to these results, Mahanmoud et al. (1979) observed decreases in hemoglobin concentrations of the animals treated with $C$. procera extract, further suggests that prolonged administration of the extract may cause anaemia due to the presence of some toxic reduced in this extract

$$
\text { The obtained results (Table, 6) }
$$
showed, highly significant $(\mathrm{P}<0.01)$ increases in the levels of serum urea $(\mathrm{mg} / \mathrm{dl})$ and creatinine $(\mathrm{mg} / \mathrm{dl})$ in both male $(\mathrm{G} 2)$ and female (G5) rabbits after administered high doses of aqueous extract of Calotropis procera only and the variations in the two previous parameters were not significant at low dose of Calotropis procera in both sex. These results go in agreement with the results of Pouokam, et al. (2011) who reported, marked increases in these parameters after administered aqueous extract of Calotropis procera.

These elevations may be due to the accumulation of toxic doses of the active principles of the plant extract, which causes damage of the kidney cells and failure of kidney functions (Eissa and Zidan, 2010). These accumulation may be cause degeneration of the tubular epithelial cells (Parke, 1982) and/or necrosis of the cells of the renal convoluted tubules (Mahmoud $\boldsymbol{e t}$ al., 1979). This reduced renal blood flow associated with higher serum urea concentration may impair the secretary function of the kidney (Whealton et al.,1994)

The obtained results elucidated, highly significant increases $(\mathrm{p}<0.01)$ of ASAT and significant $(p<0.05)$ increases in ALAT and ALP in both sex of rabbits ( G2 and G5) after administered high doses of aqueous extract of Calotropis. These increases may be due to damage/or dead liver cells under the toxic effects of high active principles of plant extract 
and cause diffusion of these enzymes from the intracellular sites (Tilkian et al., 1983 and Jimoh and Odutuga, 2001).

In contradiction to these results, Ali (2006) recorded decreases in ALAT and ASAT after 15 days of treatment with Calotropis extract (oshar). Also, Pouokam et al. (2011) observed that, no significant change was noticed in the activity of ASAT and ALP and significant decreases $(\mathrm{p}<0.05)$ were found in the activity of ALAT in smaller rabbits after administered high doses of aqueous extract of Calotropis

The obtained data (Table 4) showed that serum total protein and albumin were decreased after administered of high doses of aqueous extract of Calotropis in both sex of

\section{REFERENCES}

Ali AM (2006): Teratogenic effect and biochemical changes to some rodenticides on certain rodent species. Ph.D. (Agric. Zoology) Al-Azhar Univ.

Babson LA (1965): Phenolphalein monophosphate methods for the determination of alkaline phosphatase. Clin. Chem., 11 : 789.

Baker FJ, Silverton RE and Pallister CJ (1998): Introduction to Medical Laboratory Technology, 7th Edition. Bartholomew RJ, Delaney AM (1966). Proceedings Australian Association of Clinical Biochemistry, 1: 214.

Behera BK, Arora M and Sharma DK (2000): Studies on Biotransformation of Calotropis Procera Latex - A Renewable Source of Petroleum, Value-Added Chemicals, and Products, Energy Sources, 22 (9) 781-807.

Dada YO, Lamidi MT, Eghianruwa KI and Adepoju F (2002): Effects of oral administration of the latex of Calotropis procera on weigth, hematology and biochemistry in rats. Trop. Vet., 20: 4 . rabbits. This decreases may be a result of the damaged effect of plant extract on liver. The liver is a major organ of protein synthesis and any diseases in the liver can cause damage of hepatocytes with changes in protein and free amino acid metabolism and decreases their synthesis in the liver and increase wasting via catabolism (Yousef et al., 2006; Wallace, 2007 and El- Shafey et al., 2011).

On the other hand, Mbako (2009) observed that, Serum albumin and total proteins of rabbits showed slight variations after administration aqueous extract of fresh leaves of Calotropis procera also reported in rats (Dada $\boldsymbol{e t}$ al., 2002). These variations were not statistical significance, this may be because the liver was not greatly damaged.

Dewan S, Sangraula H, Kumar VL. (2000): Preliminary studies on the analgesic activity of latex of Calotropris procera. J Ethnopharmacol., 73(1-2):307-311.

District, R.; G. Wilson, G. and Beere,G. (1983): Toxicity experiments of ubberbush fed to cattle and sheep (Calotropis procera). Technote, 30:1-3

Doumas B, Watson W and Biggs $H$ (1971): Albumin standards and the measurement of serum albumin with bromocresol green. Clin. Chem. Acta., 31:87-90.

Doumas BT (1975): Standards for total serum protein assays. A collaborative study Clin. Chem., 21(8) : 1159-1161.

Eissa FI and Zidan NA (2010): Haematological, biochemical and histopathological alterations induced by abamectin and Bacillus thuringiensis in male albino rats. J. of Basic \& Applied Sci., 3(3): 2497-2505.

El- Shafey AAM, Seliem MME, El-Mahrouky F, Gabr WM and Kandil RA (2011): Some 
Physiological and biochemical effects of Oshar extract and abamectin biocide on male albino rats. Journal of American Science, 7(12): 254-261

Greiss EAM (1955): Anatomical Identification of plant remains and other materials from (1) ElOmari excavation at Helwan from the first dynasty. Bull Inst. Egypt., 36(1):227-235.

Guy PB, Ahmed H, Dawurung C, Atiki A, David S and Philipe O (2011): Influence of age on subchronic toxicity of the aqueous extract of the leaves of Calotropis procera on rabbits. J. Toxicol. \& Environ. Health Sci., 3 (5): 119-126.

Heinegard D and Tiderstrom G (1973): Determination of serum creatinine by a direct colorimetric method. Clinica. Chimica. Acta., 43:305-310.

Jimoh, F.O. and Odutuga, A.A. (2001): Changes in the activities of some diagnostic enzymes in some rat tissues following the consumption of thermally oxidized groundnut oil. Nig. J. Biochem. Mol. Biol.,16: 173-176.

Kumar A, Singh A and Shekhawat VP (2004): Effect of Location on the Growth and Hydrocarbon Yield of Calotropis procera: A Case Study In : Van Swaaij, Fjallstrom, Helm and Grassi (eds): Biomass for energy, industry, and climate protection. Proc.Second World Conference ETA-Florence, Rome Italy WIP-Munich, Germany, pp. 350.

Kumar A and Vijay N(2004): Studies on Laticifer Development in Calotropis procera an Important Plant Yielding Hydrocarbon and Improvement of its Growth Potential In : Van Swaaij, Fjallstrom, Helm and Grassi (eds):. Biomass for energy, industry, and climate protection. Proceedings of the Second World Conference ETA-Florence, Rome Italy WIP-Munich, Germany, pp. 176.

Lewis WH, Elvin-Lewis DMF (1977): Medical Botany: Plants that Affect Man's Health. John Wiley, London.
Mahmoud OM, Adam SEI and Tartour G (1979): The Effect of Calotropis procera on Small Ruminants. J. Comp. Path., 89: 251-263

Marsh WH, Fingerhut B and Miller H (1965):

Automated and Manual Direct Methods for the Determination of Blood Urea. Clinical Chemistry, 11: 624-627.

Mbako JD, Adamu Z, Afutu JK, Aliyu A, David S, Umar MB and Nduaka C (2009): Effects of the aqueous extract of fresh leaves of Calotropis procera on haematological and biochemical parameters in female rabbits.African Journal of Biotechnology, 8 (19):5071-5075

Millar AG and Morris M (1987): Plants of Dhofar; The Southern Region of Oman, Traditional, Economic and Medicinal Uses. The office of the Advisor for Conservation of the Environment, Diwan of Royal Court Sultanate of Oman, pp. 42.

Murti Y, Pathak B and Yogi D (2010): Pharmacognostic standardization of leaves Calotropis procera, International J. Ayurveda Res., 1(1): 14-17.

Oudhia P and Dixit A (1994): Weeds in Ambikapur region (Madhya Pradesh) and their traditional use. Weeds News. 1 (2), pp. 19-21.

Padmaja KV, Atheya N, Bhatnagar AK and Singh KK (2009): Conversion of Calotropis procera biocrude to liquid fuels using thermal and catalytic cracking. Fuel, 88 (5): 780-785.

Parke DV (1982): The Handbook of Environmental Chemistry: 1 Springer Verlag, Berlin, pp. 141-178.

Pouokam GB, Ahmed H, Dawurung C, Atiku A, David S and Philipe O (2011): Influence of age on sub-chronic toxicity of the aqueous extract of the leaves of Calotropis procera on rabbits. J. Toxicolo. and Envi. Health Sci., 3(5): 119-126:

Radunz BL, Wilson G and Beere G (1983): Toxicity Experiments of Rubberbush Fed to Cattle and Sheep (Calotropis procera). Technote, 30:1-3. 
Ratna C and Ritu S(2007): Hydrocarbons from

Calotropis procera- product enhancement and analysis, Internat. J Energy Res. 17(9): 791-799.

Reddy MSN and David K (2003): A note on the estimation of percentage of biocrude in some petrocrops, Journal of the Indian Botanical Society, 82(1-4): 40-43 .

Reithman S and Frankel S (1957): Colorimetric method for the determination of serum transaminases. Am. J. Clin. Pathol., 28: 56-63.

Sangraula H, Dewan S and Kumar VL (2002):

Evaluation of anti-inflammatory activity of latex of Calotropis procera in different models of inflammation. Inflammopharmacology, 9(3):257264.

Soto BB, JMaia dL, Freitas FJC, Amorin RNL, Camara ACL and Batista JS (2001): Clinical and pathological effects of Calotropis procera exposure in sheep and rats. Toxicon., 57: 183-185.

Tilkian SM, Conover M and Tilkian AG (1983): Clinical implications of laboratory tests. The C.V. Mosby Company, Louis, Toronto, London.
Wallace AH (2007): Principles and Methods of Toxicology. Healthcare USA, Inc., New York, NY 10017. 5th ed., pp. 369-453.

Whealton A, Watson AJ and Rock RC (1994):

Colorimetric determination of serum urea concentration. In Tietz Textbook of Clin. Chem. Burtis CA, Ashwood ER (eds.). WB Saunders Company London pp. 1528- 1531.

Yousef MI, Awad TI and Mohamed EH (2006):

Deltamethrin-induced oxidative damage and biochemical alterations in rat and its attenuation by Vitamin E. Toxicology, 227(3):240-247. 


\section{تalotropis تقيم التأثيرات السامة بعد المعاملة لفترة طويلة بالمستخلص المائي لأوراق نبات procera

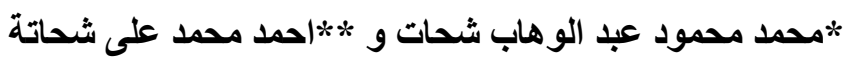

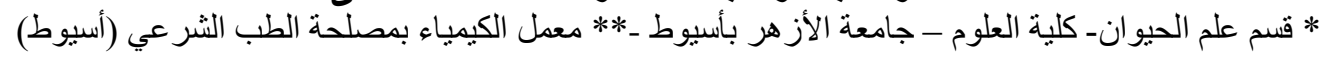 \\ Shahat_egy@hotmail.com}

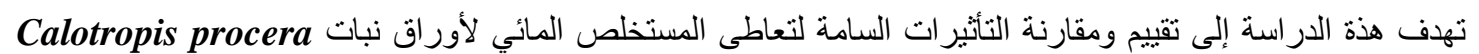

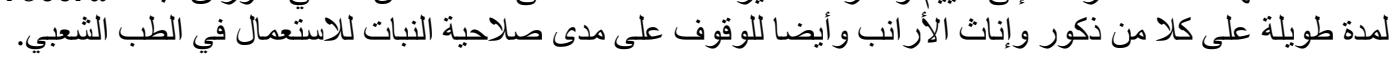

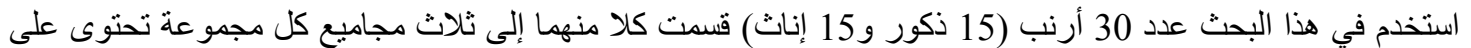

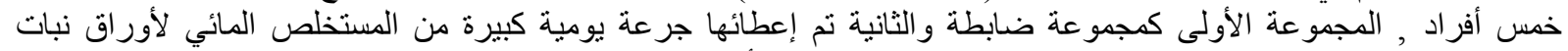
Calotropis procera المستخلص المائي لأور اق نبات Calotropis procera (40 ملجم /كجم من وزن الجسم) لمدة 8 أسابيع .

أوضحت النتائج عدم وجود اى تغيرات ذي دلالة إحصائية في وزن الجسم أو عدد كريات الدم الحمراء و البيضاء

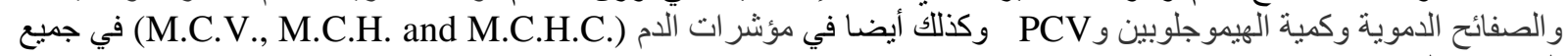
المجاميع (الذكور و الإناث)

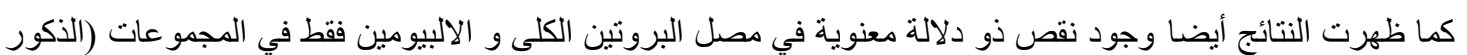

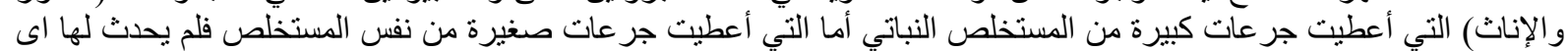
تغير ات معنوية الأنات

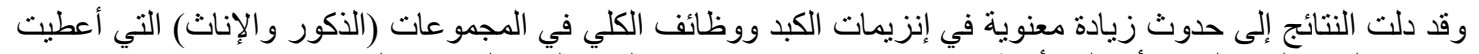

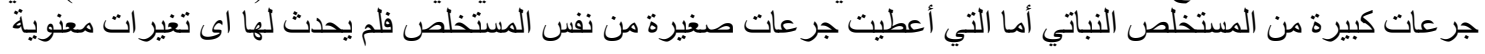

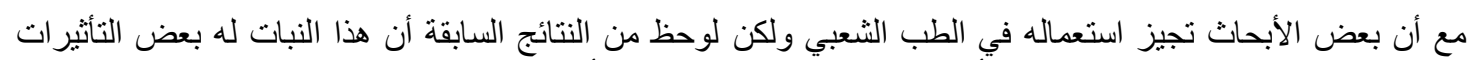

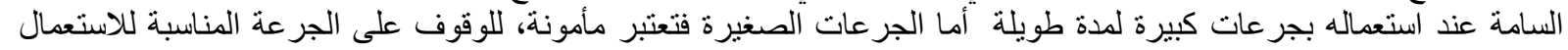
،فهذا بحاجة إلى در اسات تكميلية مستقبلية خاصة لدراسة الجر عات التراكمية على الددى البعيد. 